\title{
Kecernaan in-Vitro Ransum Berbasis Limbah Jagung Amoniasi dengan Berbagai Rasio Konsentrat untuk Ruminansia
}

\section{In-Vitro Digestibility of Ammoniated Corn Waste Basis with Variated Concentrate Ratio for Ruminants Ration}

\author{
Elihasridas dan R.Herawati \\ Fakultas Peternakan Universitas Andalas \\ Kampus Unand Limau Manis Padang, 25163 \\ e-mail: elihasridas21@yahoo.com \\ (Diterima : 30 Juni 2014 , Disetujui : 30 September 2014)
}

\begin{abstract}
ABSTRAK
Penelitian ini untuk menentukan rasio optimum penggunaan limbah jagung amoniasi dan konsentrat dalam ransum komplit ternak ruminansia berdasarkan parameter kecernaan secara invitro. Empat formula ransum komplit tersebut adalah; $\mathrm{R} 1=20 \%$ limbah jagung amoniasi dan $80 \%$ konsentrat, $\mathrm{R} 2=40 \%$ limbah jagung amoniasi dan $60 \%$ konsentrat, $\mathrm{R} 3=60 \%$ limbah jagung amoniasi dan $40 \%$ konsentrat dan R4=80\% limbah jagung amoniasi dan $20 \%$ konsentrat. Kecernaan ransum ditentukan setelah diinkubasi selama 48 jam dengan cairan rumen menurut teknik Tilley dan Terry (1969). Data dianalisis menggunakan rancangan acak kelompok. Parameter yang diukur adalah kecernaan bahan kering, bahan organik dan protein kasar, serta konsentrasi VFA dan $\mathrm{NH}_{3}$ cairan rumen. Hasil analisis menunjukkan bahwa kecernaan dan konsentrasi VFA dan $\mathrm{NH}_{3}$ berbeda nyata $(\mathrm{P}<0,05)$, namun antara R1 dan $\mathrm{R} 2$ berbeda tidak nyata $(\mathrm{P}>0,05)$. Disimpulkan bahwa $40 \%$ limbah jagung amoniasi dan $60 \%$ konsentrat yang lebih baik digunakan sebagai ransum komplit untuk ruminansia.
\end{abstract}

Kata kunci: in-vitro, limbah jagung amoniasi, konsentrat, ruminansia

\section{ABSTRACT}

The objective of this research was to determined the optimum ratio of ammoniated corn waste and concentrate in complete ruminant ration based on in-vitro digestibility. Four kinds of completed feed consisting of: $R 1=20 \%$ ammoniated corn waste and $80 \%$ concentrate, $R 2=40 \%$ ammoniated corn waste and $60 \%$ concentrate, R3=60\% ammoniated corn waste and $40 \%$ concentrate and $R 4=80 \%$ ammoniated corn waste and $20 \%$ concentrate. Digestibility was determined after 48 hours incubation with rumen fluid using Tilley and Terry technique (1969). Data were collected by a block randomized design. The measured parameters were the digestibility of dry materials, organic materials, crude protein and concentration of $\mathrm{VFA}$ and $\mathrm{NH}_{3}$ of rumen fluid. The result showed that digestibility of DM, OM, CP and concentration of VFA and $\mathrm{NH}_{3}$ has significantly effect $(P<0.05)$. But there was not significant effect between $R 1$ and $R 2(P>0.05)$. In conclusion, a compound of $40 \%$ ammoniated corn waste and $60 \%$ concentrate was a better complete feed for ruminants ration.

Keyword: in-vitro digestion, ammoniated corn waste, concentrate, ruminants

\section{PENDAHULUAN}

Pada saat ini pola penyediaan pakan ternak telah mengalami pergeseran pada upaya pemanfaatan berbagai limbah pertanian, perkebunan, peternakan, perikanan dan agro- industri. Pemanfaatan limbah pertanian sebagai pakan merupakan salah satu strategi dalam pengembangan ternak ruminansia, mengingat potensinya yang cukup besar namun belum dimanfaatkan sepenuhnya sebagai 
pakan ternak. Dilihat dari potensi jumlahnya, maka apabila dapat dimanfaatkan seluruhnya sebagai pakan akan dapat meningkatkan kapasitas tampung ternak di dalam negeri. Diantara limbah pertanian tersebut adalah jerami jagung, tongkol jagung, onggok dan daun singkong.

Jagung (Zea mays) merupakan salah satu komoditas pertanian yang memiliki arti strategis bagi perekonomian masyarakat baik sebagai pangan maupun bahan baku industri (Sudjana et al., 1991). Perkembangan industri pengolahan makanan dan pakan ternak menyebabkan peningkatan permintaan jagung di Indonesia. Seiring dengan upaya peningkatan produksi jagung yang telah dicanangkan oleh pemerintah melalui program Gema Palagung maka semakin meningkat pula ketersediaan limbahnya.

Pada umumnya limbah pertanian seperti limbah tanaman jagung memiliki kualitas yang rendah karena mengandung lignin dan silika yang relatif tinggi yang membatasi kecernaannya, sehingga pemberiannya pada ternak perlu pengolahan. Pengolahan limbah jagung dengan amoniasi urea dan suplementasi nutrien pemacu pertumbuhan mikroba rumen (asam amino rantai cabang dari daun ubi kayu dan mineral $\mathrm{P}, \mathrm{S}$ dan $\mathrm{Zn}$ ) sangat efektif meningkatkan nilai gizi limbah jagung dengan meningkatnya kadar nitrogen dan kecernaannya (Elihasridas et al., 2013).

Dari beberapa penelitian dilaporkan bahwa penggunaan berbagai limbah pertanian, perkebunan dan industrinya sebagai makanan tunggal belum memberikan penampilan produksi ternak yang optimal. Sudana dan Leng (1985) melaporkan bahwa pemberian jerami padi amoniasi secara tunggal pada ternak domba tidak mampu menyokong kebutuhan hidup pokok yang ditandai dengan penurunan bobot badan ternak. Untuk mendapatkan produksi ternak yang tinggi, pemberian konsentrat dengan komposisi dan proporsi yang tepat mutlak diperlukan.

Bertitik tolak dari kenyataan tersebut, penambahan konsentrat pada ransum basal limbah jagung amoniasi dimaksudkan untuk menutupi kebutuhan zat-zat makanan esensial yang jumlahnya kurang pada limbah jagung amoniasi. Pemberian makanan tambahan ini juga dimaksudkan untuk mengoptimumkan kondisi fermentasi dalam rumen sehingga dapat menjamin pertumbuhan dan perkembangan mikroba rumen (Elihasidas et al,.2013).

Pada percobaan ini limbah jagung amoniasi digunakan sebagai hijauan tunggal yang dikombinasikan dengan konsentrat yang terdiri dari dedak padi, onggok, bungkil inti sawit, daun ubi kayu dan titonia. Berbagai imbangan konsentrat dan limbah jagung amoniasi dalam ransum diteliti guna mendapatkan formula ransum komplit yang terbaik. Penelitian ini bertujuan untuk mencari nisbah (rasio) yang optimal antara limbah jagung amoniasi dan konsentrat sebagai formula ransum komplit ternak ruminansia yang memberikan kecernaan dan produk metabolisme rumen terbaik.

\section{METODE}

Percobaan ini dilakukan di Laboratorium Nutrisi Ruminansia Fakultas Peternakan Universitas Andalas. Limbah jagung amoniasi digunakan sebagai ransum basal yang dikombinasikan dengan berbagai taraf konsentrat. Bahan pakan penyusun konsentrat terdiri dari dedak padi, onggok, bungkil inti sawit, tepung daun ubi kayu, tepung daun titonia, garam, dan lakta mineral. Penelitian ini menggunakan Rancangan Acak Kelompok 4 x 4, dengan 4 macam ransum komplit sebagai perlakuan dan 4 kali pengambilan cairan rumen sebagai kelompok. Adapun susunan perlakuan adalah : $\mathrm{R} 1=20 \%$ limbah jagung amoniasi dan $80 \%$ konsentrat, R2 $=40 \%$ limbah jagung amoniasi

Tabel 1. Komposisi bahan pakan penyusun konsentrat

\begin{tabular}{lc}
\hline \multicolumn{1}{c}{ Bahan pakan } & Proporsi (\%) \\
\hline Dedak padi & 28,0 \\
Onggok & 20,0 \\
Bungkil inti sawit & 20,0 \\
Tepung daun ubi kayu & 15,0 \\
Tepung daun titoni & 15,0 \\
Garam & 0,5 \\
Lakta mineral & 1,5 \\
\hline Jumlah & 100,0 \\
\hline
\end{tabular}


Tabel 2. Kandungan nutrisi ransum percobaan

\begin{tabular}{|c|c|c|c|c|}
\hline \multirow[t]{2}{*}{ Kandungan Nutrisi } & \multicolumn{4}{|c|}{ Ransum Perlakuan } \\
\hline & $\mathrm{R} 1$ & $\mathrm{R} 2$ & R3 & R4 \\
\hline Protein Kasar & 77,08 & 75,32 & 73,54 & 71,77 \\
\hline Bahan Kering & 14,21 & 13,15 & 12,09 & 11,03 \\
\hline Serat Kasar & 26,30 & 31,22 & 36,14 & 41,06 \\
\hline Lemak Kasar & 5,57 & 4,68 & 3,79 & 2,90 \\
\hline T D N & 67,55 & 66,66 & 65,77 & 64,88 \\
\hline
\end{tabular}

kelompok. Adapun susunan perlakuan adalah : dan $60 \%$ konsentrat, R3 $=60 \%$ limbah jagung amoniasi dan $40 \%$ konsentrat dan $\mathrm{R} 4=80 \%$ limbah jagung amoniasi dan 20\% konsentrat. Peubah yang diamati adalah: Kecernaan bahan kering, bahan organik, protein kasar, konsentrasi VFA dan NH3 ransum.

\section{Pembuatan Limbah Jagung Amoniasi}

Limbah jagung yang terdiri dari jerami dan tongkol jagung dipotong-potong $3-5 \mathrm{~cm}$, kemudian diaduk merata dengan kotoran ayam kering sebanyak $15 \%$ dari berat kering limbah jagung. Urea dilarutkan dengan air, dengan perbandingan air yang digunakan dengan bahan kering limbah jagung adalah 1:1. Jumlah urea yang digunakan adalah $4 \%$ dari bahan kering limbah jagung (40 g urea dilarutkan dalam 1 liter air untuk $1 \mathrm{~kg}$ bahan kering limbah jagung). Limbah jagung dimasukkan ke dalam ember plastik kapasitas 50 liter selapis demi selapis kemudian disemprot dengan larutan urea dan dipadatkan supaya suasana an-aerob. Setelah ember terisi penuh lalu ditutup dengan plastik 2 lapis dan diikat dengan tali. Ember disimpan di tempat yang aman dan teduh selama 10 hari. Setelah 10 hari tutup ember dibuka, limbah jagung dikeluarkan dan dikeringkan selama 2 hari untuk menghilangkan kelebihan gas ammonia, setelah itu digiling dan siap untuk digunakan.

\section{Fermentasi Rumen in-vitro}

Pengukuran kecernaan secara in-vitro dilakukan berdasarkan prinsip Tilley dan Terry (1969). Sampel ransum yang telah dipersiapkan ditimbang sebanyak $5 \mathrm{~g}$ dan dimasukkan ke dalam fermentor (tabung erlenmeyer), ditambah dengan larutan saliva buatan (larutan Mc Dougall) sebanyak $200 \mathrm{ml}$ pada suhu $39^{\circ} \mathrm{C}$ dan $\mathrm{pH} \pm 6,9$ dan cairan rumen sapi yang masih segar sebanyak $50 \mathrm{ml}$ sebagai inokulum. Kemudian fermentor diinkubasi secara an-aerob (dengan mengalirkan gas $\mathrm{CO}_{2}$ kira-kira 30 detik) selama 48 jam dalam shaker water bath pada suhu $39^{\circ} \mathrm{C}$. Setelah 48 jam karet tutup fermentor dibuka dan ditambahkan larutan $\mathrm{HgCl}_{2}$ jenuh sebanyak $0,2 \mathrm{ml}$ untuk menghentikan fermentasi oleh mikroba rumen. Cairan fermentasi disentrifus dengan kecepatan 1200 rpm selama 20 menit, kemudian pisahkan supernatant dan endapan, saring dengan kertas saring Whatman No.41 dan endapan dikeringkan dalam oven, selanjutnya siap untuk dianalisis. Sebagai blanko digunakan cairan rumen sapi tanpa sampel. Degradasi zat-zat makanan (BK, BO dan PK) dihitung dengan persamaan sebagai berikut :

$$
B K=\frac{\begin{array}{c}
(\text { Berat sampel } x \text { BK })-(\text { Berat Residu } x \\
B K+B K \text { Blanko }) \times 100 \%
\end{array}}{\text { Berat sampel } x B K}
$$

Cara yang sama digunakan untuk menghitung degradasi BO dan PK.

\section{Analisis Statistik}

Data yang diperoleh dianalisis ragam dengan uji $\mathrm{F}$ dan apabila terdapat pengaruh perlakuan yang nyata, maka dilanjutkan dengan uji wilayah ganda Duncan's untuk mengetahui perbedaan antar perlakuan. Kriteria pengambilan keputusan pada taraf kepercayaan $95 \%$ atau $a=0,05$. Analisis data dilakukan menggunakan software statistika versi 8.0.

\section{HASIL DAN PEMBAHASAN}

\section{Kecernaan Bahan Kering, Bahan Organik dan Protein Kasar Ransum}

Rataan kecernaan in-vitro bahan kering, bahan organik dan protein kasar ransum komplit dengan berbagai rasio limbah jagung 
amoniasi dan konsentrat ditampilkan pada Tabel 3. Hasil analisis keragaman menunjukkan bahwa perbedaan rasio limbah jagung amoniasi dan konsentrat dalam ransum memberikan perbedaan yang nyata $(\mathrm{P}<0,05)$ terhadap kecernaan bahan kering, bahan organik dan protein kasar ransum.

Data Tabel 3 di bawah terlihat bahwa kecernaan bahan kering $\mathrm{R} 1$ nyata $(\mathrm{P}<0,05)$ lebih tinggi dari ransum lainnya, namun kecernaan bahan organik dan protein kasar tidak berbeda nyata $(\mathrm{P}>0,05)$ dengan $\mathrm{R} 2$ dan berbeda nyata dengan R3 dan R4. Peningkatan proporsi limbah jagung amoniasi dan penurunan proporsi konsentrat dalam ransum menurunkan kecernaan bahan kering, bahan organik dan protein kasar. Hal ini disebabkan karena peningkatan proporsi limbah jagung amoniasi dalam ransum secara langsung juga meningkatkan kadar serat kasar ransum.

Kandungan serat kasar dalam ransum merupakan salah satu faktor yang membatasi kecernaan zat-zat makanan dalam rumen, semakin tinggi serat kasar dalam ransum maka semakin rendah tingkat kecernaan zat-zat makanan ransum tersebut. Dari komposisi kimia ransum terlihat bahwa kandungan serat kasar ransum meningkat sangat nyata dari R1 sampai R4. McDonald et al. (2002) menyatakan bahwa kecernaan pakan dipengaruhi oleh komposisi kimianya dan fraksi pakan berserat berpengaruh besar terhadap kecernaan zat-zat makanan. Hal yang sama juga dijelaskan oleh Saili et al. (2007) bahwa tingginya kandungan serat kasar dalam ransum menurunkan daya cerna zat-zat makan dalam ransum tersebut.

Selain kandungan serat kasar yang mempengaruhi kecernaan ransum juga ditentukan oleh kandungan energi dan protein ransum. Suplai energi dan protein yang cukup dan seimbang akan mengoptimalkan kondisi fermentasi dalam rumen. Bioproses rumen sangat dipengaruhi oleh populasi dan aktifitas mikroba rumen dan fermentabilitas pakan. Mikroba rumen merupakan ujung tombak pencernaan makanan dalam rumen, semakin tinggi populasi mikroba dalam rumen semakin tinggi pula laju degradasi zat makanan dalam rumen. Laju pertumbuhan mikroba maksimum dapat dicapai apabila pasokan semua nutrient yang diperlukan untuk pertumbuhan dan perkembangan mikroba tersedia dalam konsentrasi optimum (Elihasridas et al., 2011). Kecernaan bahan kering, bahan organik dan protein kasar ransum nyata menurun dengan menurunnya proporsi konsentrat dalam ransum.

Menurunnya proporsi konsentrat dalam ransum mengakibatkan berkurangnya suplai zat makanan terutama energi dan protein untuk mikroba rumen sehingga menurunkan populasi dan aktifitas mikroba rumen. Penambahan konsentrat sebagai sumber protein, karbohidrat dan mineral dapat meningkatkan pemanfaatan jerami padi yang ditandai oleh peningkatan konsumsi dan daya cerna serta pertambahan bobot badan pada ternak ruminansia (Church and Santos, 1981 dan Liu et al., 1988). Hal tersebut juga dilaporkan oleh Warly (1994), bahwa pemberian bungkil kedelai atau gandum pada domba yang diberi makan jerami padi amoniasi, menghasilkan tingkat fermentasi rumen dan daya cerna zatzat makanan yang lebih tinggi, serta retensi nitrogen dan pertambahan bobot badan yang lebih baik dibanding dengan tanpa pemberian konsentrat.

Selanjutnya dinyatakan bahwa dengan pemberian kombinasi gandum (sebagai sumber energi) dan bungkil kedelai (sebagai sumber protein), jerami padi dapat dicerna jauh lebih tinggi dibanding dengan hanya pemberian bungkil kedelai atau gandum saja. Peningkatan ini disebabkan oleh keadaan optimum kondisi rumen yang menunjang aktifitas mikroba rumen sehingga dapat mencerna dengan baik zat-zat makanan ransum yang diberikan. Kecernaan bahan organik dan protein kasar R1 (20\% limbah jagung amoniasi dan $80 \%$ konsentrat) tidak nyata berbeda ( $>>0,05)$ dengan R2 (40\% limbah jagung amoniasi dan $60 \%$ konsentrat).

Hal ini diduga pasokan energi dan nitrogen untuk pertumbuhan mikroba sudah mencukupi atau kondisi fermentasi sudah 
Tabel 3. Rataan kecernaan bahan kering, bahan organik dan protein kasar ransum

\begin{tabular}{ccccc}
\hline Peubah & \multicolumn{4}{c}{ Formula Ransum } \\
\cline { 2 - 5 } & R1 & R2 & R3 \\
\hline Kec. Bhn. Kering (\%) & $70,23^{\mathrm{a}}$ & $65,18^{\mathrm{b}}$ & $53,93^{\mathrm{c}}$ & $44,09^{\mathrm{d}}$ \\
Kec. Bhn. Organik (\%) & $78,41^{\mathrm{a}}$ & $73,74^{\mathrm{a}}$ & $60,26^{\mathrm{b}}$ & $53,12^{\mathrm{c}}$ \\
Kec. Protein Kasar (\%) & $74,86^{\mathrm{a}}$ & $72,70^{\mathrm{a}}$ & $59,07^{\mathrm{b}}$ & $51,57^{\mathrm{c}}$ \\
\hline
\end{tabular}

Keterangan : Nilai dengan superskrip berbeda pada baris yang sama menunjukkan berbeda nyata $(\mathrm{P}<0,05)$.

Tabel 4. Rataan $\mathrm{pH}$, kadar VFA dan $\mathrm{NH}_{3}$ cairan rumen

\begin{tabular}{lrrrr}
\hline \multirow{2}{*}{ Peubah } & \multicolumn{4}{c}{ Formula Ransum } \\
\cline { 2 - 5 } & $\mathrm{R} 1$ & $\mathrm{R} 2$ & $\mathrm{R} 3$ \\
\hline $\mathrm{pH}$ & 6,87 & 6,89 & 7,01 & 6,97 \\
$\mathrm{VFA}(\mathrm{mM})$ & $140,14^{\mathrm{a}}$ & $137,32^{\mathrm{a}}$ & $121,97^{\mathrm{b}}$ & $115,52^{\mathrm{c}}$ \\
$\mathrm{NH}_{3}(\mathrm{mg} / 100 \mathrm{ml})$ & $12,86^{\mathrm{a}}$ & $10,18^{\mathrm{b}}$ & $8,37^{\mathrm{c}}$ & $6,84^{\mathrm{d}}$ \\
\hline
\end{tabular}

Keterangan : Nilai dengan superskrip berbeda pada baris yang sama menunjukkan berbeda nyata $(\mathrm{P}<0,05)$.

optimal. Tyler dan Ensminger (2006) menyatakan bahwa apabila kebutuhan mikroba rumen telah terpenuhi maka populasi dan jumlah mikroba sudah optimal sehingga proses fermentasi juga sudah optimal.

\section{Karakteristik Cairan Rumen Media in- Vitro}

Kondisi rumen yang optimal untuk aktifitas dan perkembang biakan mikroba merupakan sarat mutlak yang harus dipenuhi untuk menunjang proses fermentasi yang tinggi. Pada umumnya faktor utama yang dapat dijadikan kriteria dalam menilai kondisi rumen, yaitu $\mathrm{pH}$, konsentrasi VFA dan $\mathrm{NH}_{3}$ cairan rumen. Produk metabolisme rumen seperti kadar VFA dan $\mathrm{NH}_{3}$ cairan rumen mencerminkan tingkat fermentabilitas ransum dalam rumen. Makin tinggi produk metabolis me rumen tersebut terbentuk menunjukkan ransum tersebut makin mudah didegradasi dalam rumen. Rataan nilai $\mathrm{pH}$, kadar VFA dan $\mathrm{NH}_{3}$ cairan rumen disajikan pada Tabel 4.

Hasil analisis ragam memperlihatkan bahwa $\mathrm{pH}$, pada masing-masing formula ransum tidak berbeda nyata $(\mathrm{P}>0,05)$ dan berada pada kisaran $6,87-7,01$. Nilai $\mathrm{pH}$ yang dihasilkan pada masing-masing formula ransum berada pada kisaran yang telah memenuhi syarat untuk menjamin aktifitas mikroba rumen, yaitu $\mathrm{pH}$ rumen yang ideal untuk perkembangan mikroba rumen adalah 6,0-7,0.

Hasil analisis ragam menunjukkan bahwa perbedaan rasio limbah jagung amoniasi dan konsentrat dalam formula ransum komplit nyata berbeda $(\mathrm{P}<0,05)$ terhadap konsentrasi VFA dan $\mathrm{NH}_{3}$ cairan rumen. Pola produksi VFA dan $\mathrm{NH}_{3}$ sama dengan pola degradasi bahan kering, bahan organik dan protein kasar ransum. Semakin tinggi proporsi konsentrat dalam formula ransum, semakin tinggi pula produksi VFA dan $\mathrm{NH}_{3}$ ransum tersebut. Produksi VFA dan $\mathrm{NH}_{3}$ mencerminkan tingkat fermentabilitas suatu bahan, karena semakin tinggi tingkat fermentabilitas suatu bahan maka semakin besar pula produksi VFA dan $\mathrm{NH}_{3}$ yang dihasilkan (Orskov dan Ryle, 1990).

Produksi VFA R1 (20\% limbah jagung amoniasi dan $80 \%$ konsentrat) tidak berbeda nyata dengan R2 (40\% limbah jagung amoniasi dan $60 \%$ konsentrat) dan berbeda nyata dengan R3 dan R4. Pola produksi VFA ini sama dengan pola degradasi bahan kering, bahan organik dan protein kasar ransum. Secara umum konsentrasi VFA yang dihasilkan pada masing-masing ransum telah memenuhi kebutuhan VFA untuk pertumbuhan mikroba yang optimal. Menurut Van Soest (2006) kisaran VFA yang dibutuhkan untuk pertumbuhan mikroba rumen yang optimal adalah $80-160$ $\mathrm{mM}$.

Kadar amonia $\left(\mathrm{NH}_{3}\right)$ dalam rumen merupakan petunjuk antara proses degradasi dan proses sintesis protein oleh mikroba. Namun, konsentrasi amonia bukanlah satu satunya, pertumbuhan mikroba dan pembentukan protein tubuhnya juga tergantung pada ketersediaan energi yang tercermin dari produksi VFA. Sama dengan konsentrasi VFA kadar 
amonia R1 tidak nyata berbeda dengan R2 dan berbeda nyata dengan R3 dan R4 mengikuti pola degradasi protein kasar. Konsentrasi ammonia menurun dari R1 sampai R4 karena penurunan proporsi konsentrat dalam ransum. Konsentrasi $\mathrm{NH}_{3}$ dalam rumen merupakan hasil dari degradasi protein dan NPN oleh mikroba rumen. Meningkatnya kadar protein dan NPN dalam ransum juga meningkatkan kadar $\mathrm{NH}_{3}$ dalam rumen.

Produksi $\mathrm{NH}_{3}$ yang dihasilkan dari masing-masing formula ransum komplit berbasis limbah jagung amoniasi ini berkisar antara 6,84-12,86 mg/100 ml cairan rumen. Kadar $\mathrm{NH}_{3}$ yang dihasilkan ini sudah mencukupi untuk memenuhi kebutuhan mikroba rumen, kebutuhan minimum mikroba rumen terhadap $\mathrm{NH}_{3}$ adalah $5 \mathrm{mg} / 100$ cairan rumen (Satter dan Slyter, 1974).

\section{KESIMPULAN}

Hasil penelitian menunjukkan bahwa perbedaan rasio limbah jagung amoniasi dan konsentrat dalam formula ransum komplit menghasilkan kecernaan, produksi VFA dan $\mathrm{NH}_{3}$ yang nyata berbeda. Kecernaan, produksi VFA dan NH3 tertinggi diperoleh pada formula ransum $\mathrm{R} 1$, tetapi tidak nyata berbeda dengan R2. Formula ransum R2 (40\% limbah jagung amoniasi dan $60 \%$ konsentrat) lebih ideal karena nilai kecernaannya tidak berbeda dengan ransum R1 dan lebih ekonomis karena proporsi konsentratnya lebih rendah dari ransum R1.

\section{DAFTAR PUSTAKA}

Church, D.C. and A. Santos. 1981. Effect of graded levels of soybean meal and nonprotein nitrogen molasses supplement on consumption and digestibility of wheat straw. J. Anim.Sci. 59 : 1609-1615.

Elihasridas, F. Agustin dan Erpomen. 2011. Suplementasi nutrisi terpadu pada ransum berbasis limbah pertanian untuk meningkatkan produktifitas dan kualitas daging ternak ruminansia. Laporan penelitian Hibah Bersaing XVII/II Perguruan Tinggi tahun anggaran 2011.
Elihasridas, F. Agustin dan Erpomen. 2013. Perpaduan teknik pengolahan dan optimalisasai bioproses rumen pada pakan limbah pertanian untuk meningkatkan produktifitas dan kualitas daging ternak ruminansia. Laporan penelitian Hibah Bersaing Perguruan Tinggi tahun anggaran 2013.

Liu, J.X., M.Okubo and Y. Asahida. 1988. Effects of soybean meal supplementation on fiber digestion in the rumen and voluntary intake of rice straw by sheep. Jpn. Zootech.Sci., 59 (12) : 1034-1039.

McDonald, P. R.A. Edwards, and J.P.D. Greenhalg. 2002. Animal Nutrition. Sixth Ed. Prentice hall. Gosport. London. Pp: 427-428.

Orskov, E.R. and M. Ryle. 1990. Energy Nutrition in Ruminant. Elsevier Appl. Sci. London

Saily, T., A. Bain, dan L. Nafiu. 2007. Peningkatan pertumbuhan sapi bali jantan muda melalui perbaikan manajemen pakan. Jurusan Peternakan, Fakultas Pertanian Universitas Haluoleo, Kendari.

Satter, L.D. and L.L. Slyter. 1974. Effect of ammonia concentration on rumen microbial production in-vitro. Brit. J. Nutr.32 : 194-208.

Sudana, I.B. and R.A. Leng. 1985. Supplementation of urea treated rice straw with lucerne hay, fishmeal or fishmeal plus Lucerne hay. In. Ruminant Feeding Systems Utilyzing Fibrous Agriculture Residues. Ed.by R.M. Dixon. School of Agiculture and Forestry, University of Melbourne, Parkvile, Victoria. : 155164.

Sudjana, J.A., Rifih dan M. Sudjadi. 1991. Jagung. Badan Penelitian dan Pengembangan Petani. Bogor.

Tilley, J.M., and R.A. Terry. 1969. A two stage technique for in-vitro digestion of forage crops. J. Br. Grasland Society 18 (2): 104-111. 
Tyler, H.D., and M.E. Ensminger. 2006. Dairy cattle science. $4^{\text {th }}$ Edition. Pearson Prentice Hall, New Jersey.

Van Soest, P.J. 2006. Rice Straw The Role of Silica and Treatment to Improve Quality. J.Anim.Feed. Sci. And Technology Volume 130. 137-171.
Warly, L. 1994. Study on improving nutritive value of rice straw and physicchemical aspects of its digestion in sheep. Ph.D. Thesis. The United Graduate School of Agriculture Sciences, Tottori University, Japan. 